\title{
Thessaloniki Mud Volcano, the Shallowest Gas Hydrate-Bearing Mud Volcano in the Anaximander Mountains, Eastern Mediterranean
}

\author{
C. Perissoratis, ${ }^{1}$ Chr. Ioakim, ${ }^{1}$ S. Alexandri, ${ }^{2}$ J. Woodside, ${ }^{3}$ P. Nomikou, ${ }^{2}$ A. Dählmann, ${ }^{4}$ \\ D. Casas, ${ }^{5}$ K. Heeschen, ${ }^{6}$ H. Amman, ${ }^{7}$ G. Rousakis, ${ }^{2}$ and V. Lykousis ${ }^{2}$
}

${ }^{1}$ Institute of Geology and Mineral Exploration, Entrance C, Spyrou Louis 1, Olympic Village, Acharne, 13677 Athens, Greece

${ }^{2}$ Hellenic Centre for Marine Research, 46th km Athens-Sounion BP712, 19013 Anavyssos, Greece

${ }^{3}$ Department of Sedimentary and Marine Geology, Vrije Universiteit Amsterdam, De Boelelaan 1085, 1081 HV Amsterdam, The Netherlands

${ }^{4}$ Department of Geochemistry, Faculty of Earth Sciences, Utrecht University, 80021 Budapestla-an 4, 3508 TA Utrecht, The Netherlands

${ }^{5}$ Institut de Sciences del Mar, Paseo Maritimo de la Barceloneta 37-49, 08003 Barcelona, Spain

${ }^{6}$ Bundesanstalt für Geowissenschaften und Rohstoffe Geozentrum Hannover, Stilleweg 2, D-30655 Hannover, Germany

${ }^{7}$ Technische Universität Berlin, Mullerv Bresslau Strasse, 10623 Berlin, Germany

Correspondence should be addressed to C. Perissoratis, perissoratis@yahoo.gr

Received 2 June 2011; Revised 16 August 2011; Accepted 12 September 2011

Academic Editor: Michela Giustiniani

Copyright () 2011 C. Perissoratis et al. This is an open access article distributed under the Creative Commons Attribution License, which permits unrestricted use, distribution, and reproduction in any medium, provided the original work is properly cited.

A detailed multibeam survey and the subsequent gravity coring carried out in the Anaximander Mountains, Eastern Mediterranean, detected a new active gas hydrate-bearing mud volcano (MV) that was named Thessaloniki. It is outlined by the $1315 \mathrm{~m}$ bathymetric contour, is $1.67 \mathrm{~km}^{2}$ in area, and has a summit depth of $1260 \mathrm{~m}$. The sea bottom water temperature is $13.7^{\circ} \mathrm{C}$. The gas hydrate crystals generally have the form of flakes or rice, some larger aggregates of them are up to $2 \mathrm{~cm}$ across. A pressure core taken at the site contained $3.1 \mathrm{lt}$. of hydrocarbon gases composed of methane, nearly devoid of propane and butane. The sediment had a gas hydrate occupancy of $0.7 \%$ of the core volume. These characteristics place the gas hydrate field at Thessaloniki MV at the upper boundary of the gas hydrate stability zone, prone to dissociation with the slightest increase in sea water temperature, decrease in hydrostatic pressure, or change in the temperature of the advecting fluids.

\section{Introduction: Purpose of This Study}

The occurrence of mud volcanoes (MVs), mud diapirs, and fluid seeps has long been known in various different geological environments of the Eastern Mediterranean [1] and in the Aegean Sea [2]. They occur not only in regions of compressional stress present in subduction zones (e.g., Calabrian Arc [3], Mediterranean Ridge [4], and orogenic belts $[1,5-7])$, but also on passive rifted margins such as the Egyptian offshore $[8,9]$ and areas of mixed tectonic signature like the ANAXIMANDER Mountains where mud volcanism is related to faults with normal and transcurrent faulting components [10-12]. Especially the accretionary prism of the Hellenic Arc (Mediterranean Ridge) is an area where a large number of mud volcanoes have been studied following their discovery in the late 1970s [13]. Mud volcanoes are also known for their high methane fluxes, advecting methanerich fluids at seafloor seeps, gas hydrates, and favorable environments for chemosynthetic symbiotic fauna $[5,10,12]$.

The Anaximander Mountains are situated between the Hellenic and Cyprus Arcs at the junction of the African Plate with the Anatolian and the Aegean microplates, an area accommodating the relative motion between the African and Eurasian plates $[6,10,14]$. The mountains have thus undergone a complex deformation including southward directed thrusting, northeast-southwest shearing in the west (Strabo Trough trend) and northwest-southeast shearing in the east (Florence Rise trend), and cross-cutting normal faulting, all defining the current structure of the mountains $[10,12,15,16]$. They are comprised of three 
main seamounts: Anaximander, Anaximenes, and Anaxagoras (Figure 1(a)).

The setting of the Anaximander Mountains is clearly favorable for the occurrence of mud volcanoes (Figure 1) thanks to the presence of overpressured fluids and faults that act as conduits for the fluids to escape $[12,17,18]$. Discovered during the Dutch ANAXIPROBE project by multibeam surveying in 1995, seven large mud volcanoes were sampled in $1996[6,7,11]$ when the first gas hydrates samples in the Mediterranean Sea were collected from Kula MV. By 2002 the Amsterdam and Kazan MVs were also discovered to have hydrates. Between 2003 and 2005 the EC-funded project ANAXIMANDER targeted these mud volcanoes in a study of the gas hydrates and associated deep biosphere in the area, and this was followed by the HERMES project (2005-2009). During these projects gas hydrates from Amsterdam and Kazan MVs were collected and studied, and two new mud volcanoes named Athina and Thessaloniki were also discovered, sampled, and studied (Figure 1(b) [17, 19-21]).

Since Thessaloniki MV is the shallowest known GH bearing MV in the Eastern Mediterranean, very briefly described earlier $[17,21]$, the purpose of this study is to carry out detailed analyses and examination of all data collected in this area and discuss the conditions and characteristics of the GH present.

\section{Materials and Methods}

The data examined in this study were acquired mainly during two cruises of the R/V Aegaeo in May 2003 and October-November 2004. During the first cruise detailed swath bathymetry and backscatter imagery of the study area was obtained using a hull-mounted SEABEAM 2120 swath system operating at $20 \mathrm{KHz}$. It has an angular sector of $150^{\circ}$, with 159 beams and a swath width from 7.5- to 11.5- times the water depth, for depths from 1 to $5 \mathrm{~km}$ respectively. Navigation was carried out with a Trimble 4000 GPS providing the ships position to within $\pm 10 \mathrm{~m}$. The bathymetric map of Thessaloniki MV (Figure 2) was produced using a $20 \mathrm{~m}$ grid interval and plotted with a Mercator projection at a scale of $1: 20.000$ with $5 \mathrm{~m}$ contours. Sediment was sampled with a $3 \mathrm{~m}$ long $73 \mathrm{~cm}$ i.d. Benthos Instruments Gravity Corer with presplit sleeves to reduce the time needed to open and sample the cores. The time between coring the seafloor and on board sampling of cores from a depth of $2000 \mathrm{~m}$ was thus reduced to between 20 and 25 minutes to ensure the least possible gas hydrate dissociation and sediment distortion. As soon as the cores were opened, the temperature of the sediments was measured, and any gas hydrates were collected and placed in a freezer at $-70^{\circ} \mathrm{C}$. Detailed sampling of the sediment followed.

The pressure coring was carried out using the APCA (Autoclave Piston Corer Anaximander) [22] designed and fabricated by Technical University of Berlin as part of the ANAXIMANDER project. The APCA retrieves cores of $10 \mathrm{~cm}$ diameter and up to a length of $250 \mathrm{~cm}$ in water depths of up to $2500 \mathrm{~m}$. It preserves the sediment cores under in situ pressure conditions [22]. Upon retrieval on deck the autoclave corer was placed upright for controlled degassing and kept in an ice bath to prevent warming to deck temperatures. The degassing, gas collection, and gas-subsampling were carried out using a valve system as described by Heeschen et al. [19], a method used and described also by others [18]. The pressure was constantly monitored and the increasing volume of released gas was read off from a converted graduated cylinder. Gas subsamples were taken via a three-port valve and were stored for analysis in the laboratory [22]. A total of four gravity cores and one autoclave core were collected at Thessaloniki MV (Figure 2, Table 1). The trace and main elements were analyzed by the X-ray diffraction method using a SIEMENS D-500 instrument. The crystalline phases were determined using the Joint Committee Power Diffraction Standards and their final semiquantitative analyses by using the EVA program from Siemens/Bruker/Socabimo.

\section{Results and Discussion}

3.1. Bathymetry and Backscattering Imaging. Anaximenes Mountain (Figure 1) is a slightly northwestward concave feature occupying the shallowest $(680 \mathrm{~m})$ and smallest area in the Anaximander Complex, and therefore is characterized by steep slopes and rugged relief. To the south the Mediterranean Ridge is terminated in the form of a flat slightly wavy or folded area lying at a water depth of about $2800 \mathrm{~m}$. It is separated from Anaximenes Mountain by a deep valley $(>3000 \mathrm{~m})$. The study of the combined $3 \mathrm{D}$ seabed morphology and backscatter intensity revealed in the southeastern slope of Anaximenes Mountain numerous dome-like morphological features with strong backscatter that constitute potential mud volcano sites. Following image processing of the backscatter data, a number of high backscatter areas implying potential active mud volcanism were identified. One of these sites at a depth of $1798 \mathrm{~m}$ was subsequently surveyed in 2003 and discovered to be a mud volcano which was named Athina MV (Figure 1, [17, 20]). In the same area, about $9 \mathrm{~km}$ northeast of Athina MV (at $35^{\circ}$ $28.60 \mathrm{~N}-30^{\circ} 15.06 \mathrm{E}$ ), and at water depths between 1320 and $1260 \mathrm{~m}$ the Thessaloniki MV was discovered after surveying and sampling in November 2004 (Figures 1 and $2[17,21]$ ). This mud volcano had not been fully examined in previous cruises because of its small size and location at the base of a very steep sloping cliff (Figure 2), although its eastern side was crossed during the ANAXIPROBE ORETech side scan survey [7] (Figure 2). It is an oval submarine hill with its long axis about $1750 \mathrm{~m}$ as defined by the $1315 \mathrm{~m}$ isobath, with steep northern and eastern slopes and an area of about $1.67 \mathrm{~km}^{2}$. In the inner part, near the summit, it becomes more circular where three peaks are distinguished, two in the west outlined by the $1260 \mathrm{~m}$ contour and one in the east at $1265 \mathrm{~m}$. Its small size and location on a steep slope made it a lower priority for investigation during earlier research projects.

3.2. Sedimentology. Five cores were collected from Thessaloniki MV: four gravity cores (AX46-GC1, AX47-GC1, 


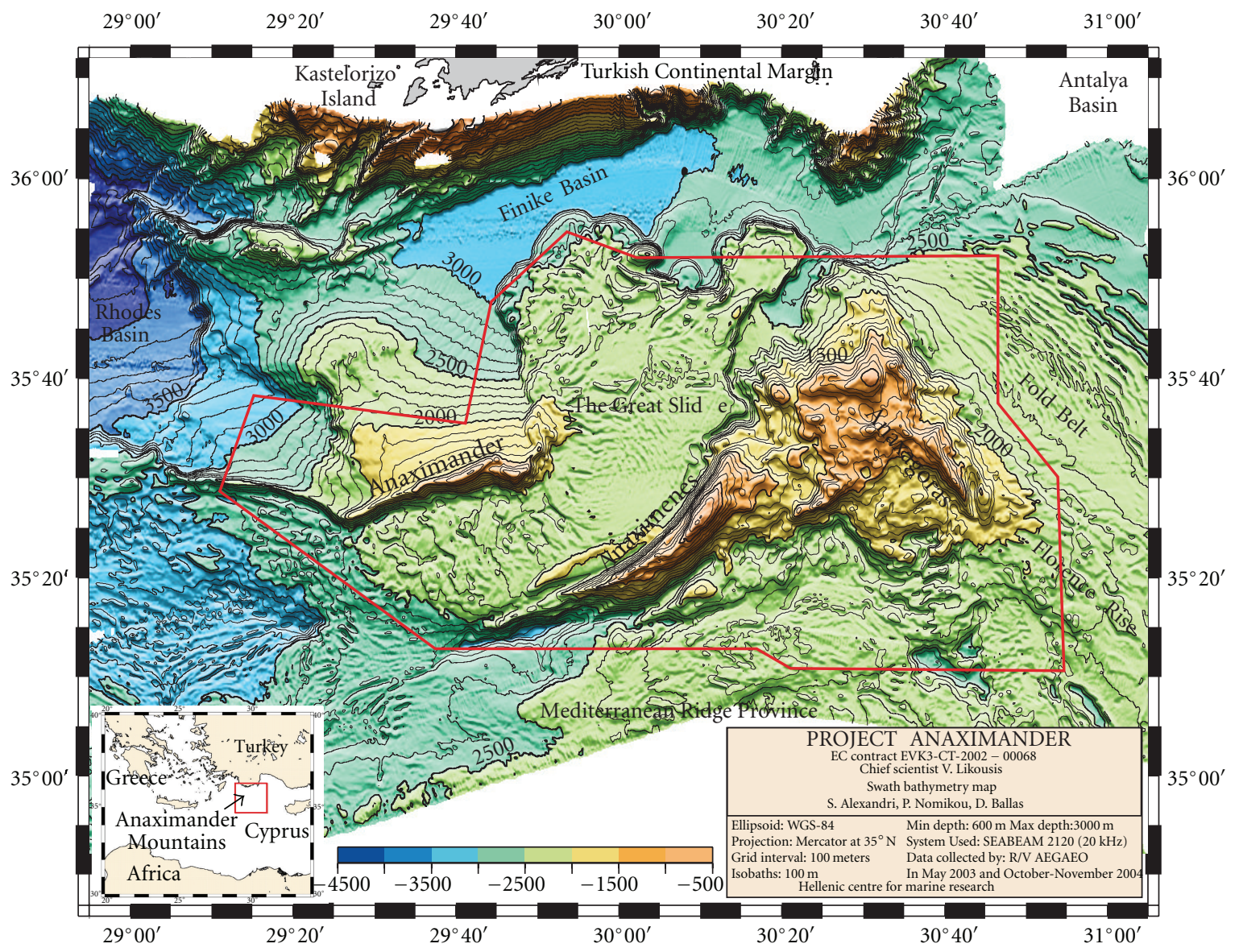

(a)

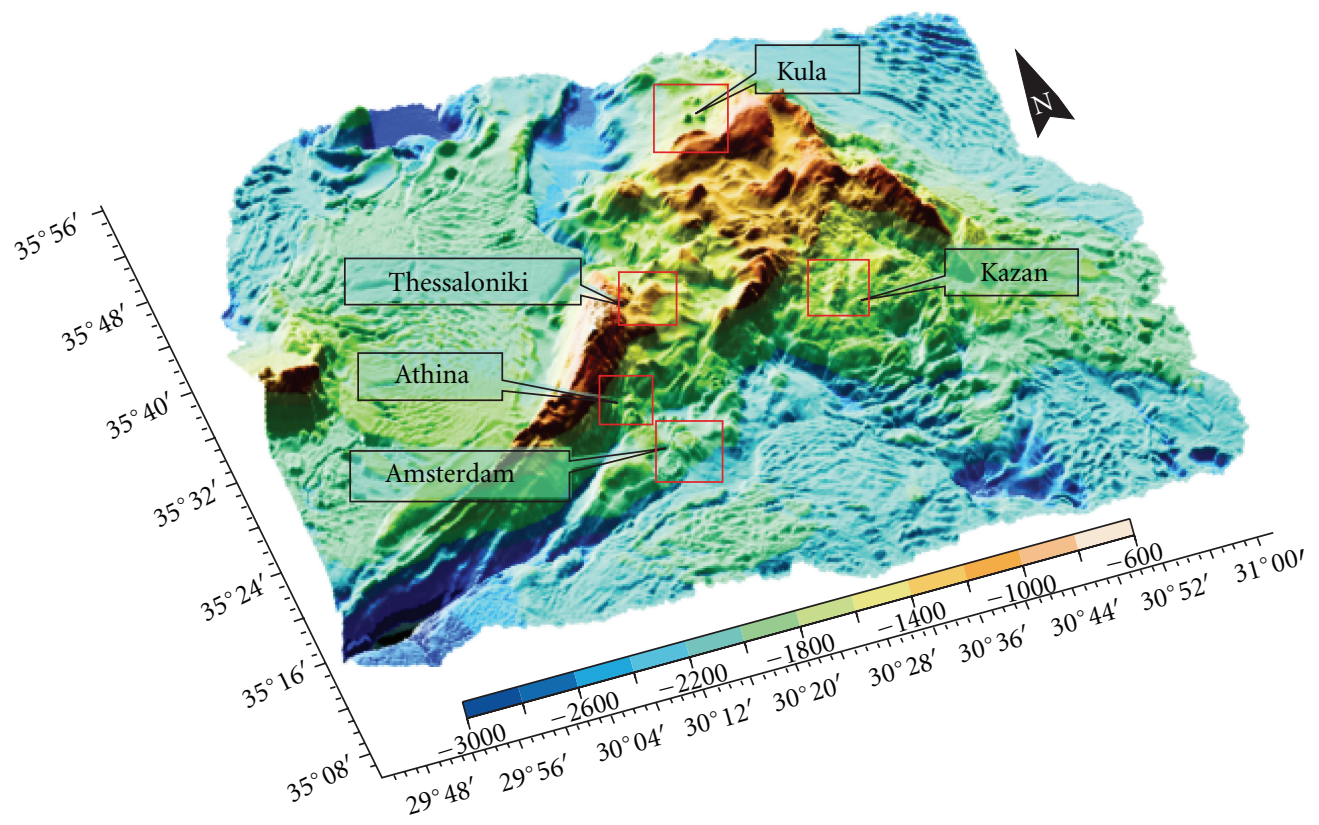

(b)

FIGURE 1: Bathymetry-physiography of the Anaximander complex (a), and swath bathymetry with locations of the five surveyed mud volcanoes ((b) from [17] supplemented with ANAXIPROBE data to outline each MV area [11]). 


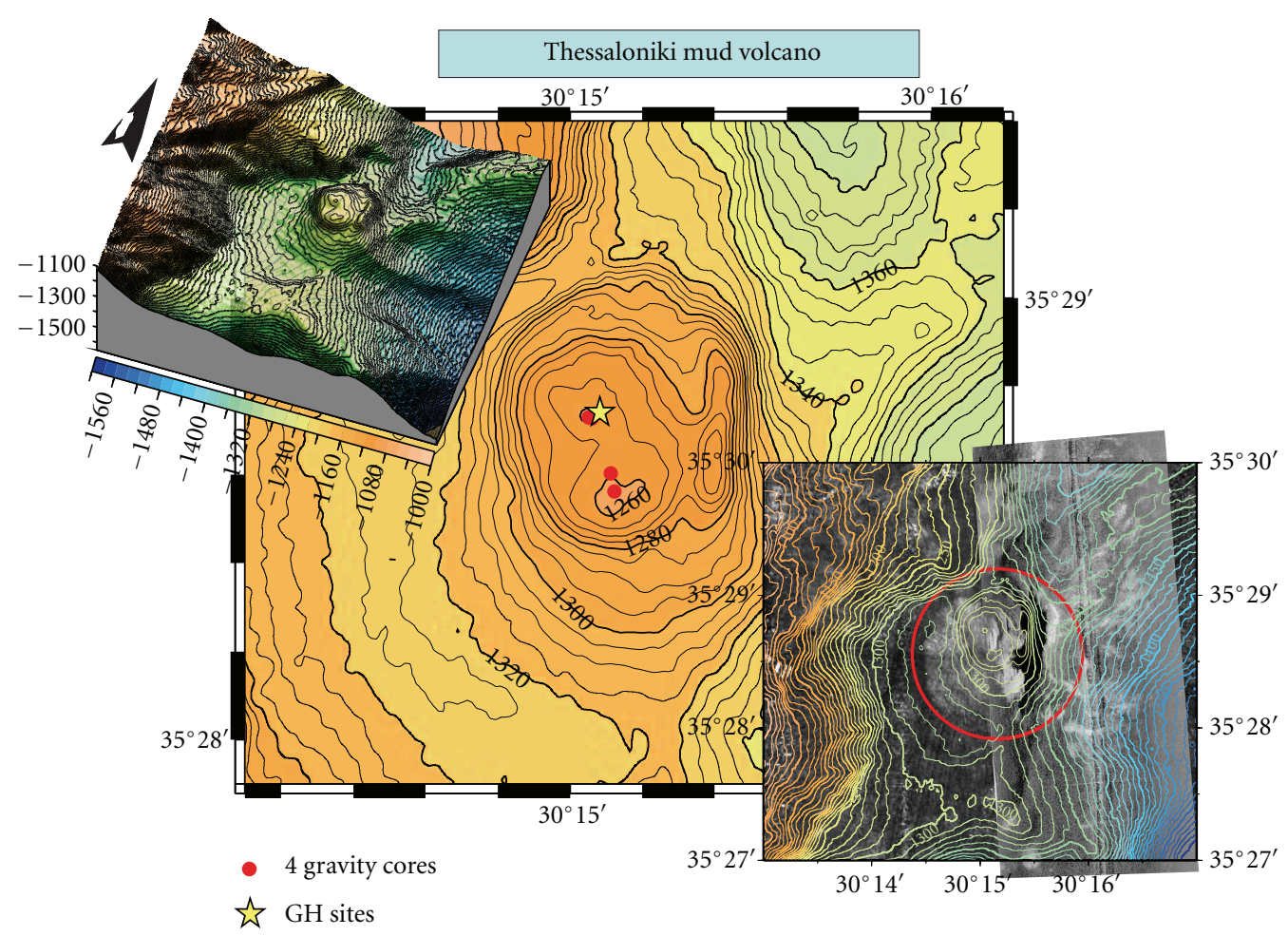

FIGURE 2: Swath bathymetry map of Thessaloniki MV and location of the collected cores (black dots). Upper left, greater swath map with the volcano at the center, lower right, ORETech side scan image from ANAXIPROBE cruise on top of SEABEAM backscatter intensity map. Gravity cores AX46-GC1, AX47-GC1, and autoclave core AX49-AP1 were retrieved from the northern peak, nearly at the same location. Gravity cores AX-48 and AX-49 were retrieved from the southern peak (from [17] supplemented with back scatter data and location of APCA core).

Table 1: (a) Gravity cores. (b) Autoclave core.

(a)

\begin{tabular}{lccccccc}
\hline Core no. & Latitude & Longitude & $\begin{array}{c}\text { Water depth } \\
(\mathrm{m})\end{array}$ & $\begin{array}{c}\text { Sediment } \\
\text { temperature }\end{array}$ & $\begin{array}{c}\text { Length } \\
(\mathrm{cm})\end{array}$ & $\begin{array}{c}\text { G.H. presence } \\
\text { (visual identification) }\end{array}$ & $\begin{array}{c}\text { Smell of } \\
\mathrm{H}_{2} S \text { gas }\end{array}$ \\
\hline AX46-GC1 & $35^{\circ} 28.603^{\prime}$ & $30^{\circ} 15.113^{\prime}$ & 1263 & $14,4^{\circ} \mathrm{C}$ & 110 & No & Yes \\
AX47-GC1 & $35^{\circ} 28.562^{\prime}$ & $30^{\circ} 15.123^{\prime}$ & 1265 & $12,3^{\circ} \mathrm{C}$ & 167 & No & Yes \\
AX48-GG1 & $35^{\circ} 28.729^{\prime}$ & $30^{\circ} 15.052^{\prime}$ & 1264 & $8.4-10.7^{\circ} \mathrm{C}$ & 130 & Yes & Yes \\
AX49-GC1 & $35^{\circ} 28.728^{\prime}$ & $30^{\circ} 15.060^{\prime}$ & 1264 & No data & 228 & Yes & Yes \\
\hline
\end{tabular}

(b)

\begin{tabular}{lccccccc}
\hline Core no. & Latitude & Longitude & $\begin{array}{c}\text { Water depth } \\
(\mathrm{m})\end{array}$ & $\begin{array}{c}\text { Length } \\
(\mathrm{cm})\end{array}$ & $\begin{array}{c}\text { Pressure } \\
(\text { bars})\end{array}$ & $\begin{array}{c}\text { GH presence } \\
(\text { litres })\end{array}$ \\
\hline AX49-AP1 & $35^{\circ} 28.728^{\prime}$ & $30^{\circ} 15.060^{\prime}$ & 1.264 & 0.70 & 105 & Yes & 3.1 \\
\hline
\end{tabular}

AX48-GC1, and AX49-GC1) and one autoclave core (AX49AP1). They are located in similar sedimentary environments on the two western highs on the summit of Thessaloniki MV (Figure 2), in water depths from 1263 to $1265 \mathrm{~m}$. Table 1 presents the details of the core locations and characteristics, with the initial deck observations made to determine whether there were gas hydrates (even if not actually observed; for example, with sediment temperatures below the seafloor temperature, $\sim 13.7^{\circ} \mathrm{C}$, there is likely to have been dissociating gas hydrates present). These observations confirmed that this MV is an active gas hydrate bearing mud volcano, the fourth discovered in the Mediterranean.

The general appearance of typical mud breccia cores (Figure 3) is of a very poorly sorted sediment with muddy matrix-supported angular to subangular clasts (xenoliths) of different compositions and grain sizes $(0.5$ to $2.5 \mathrm{~cm})$. The clasts reflect the geological units through which the overpressured sediment passed before erupting on the 


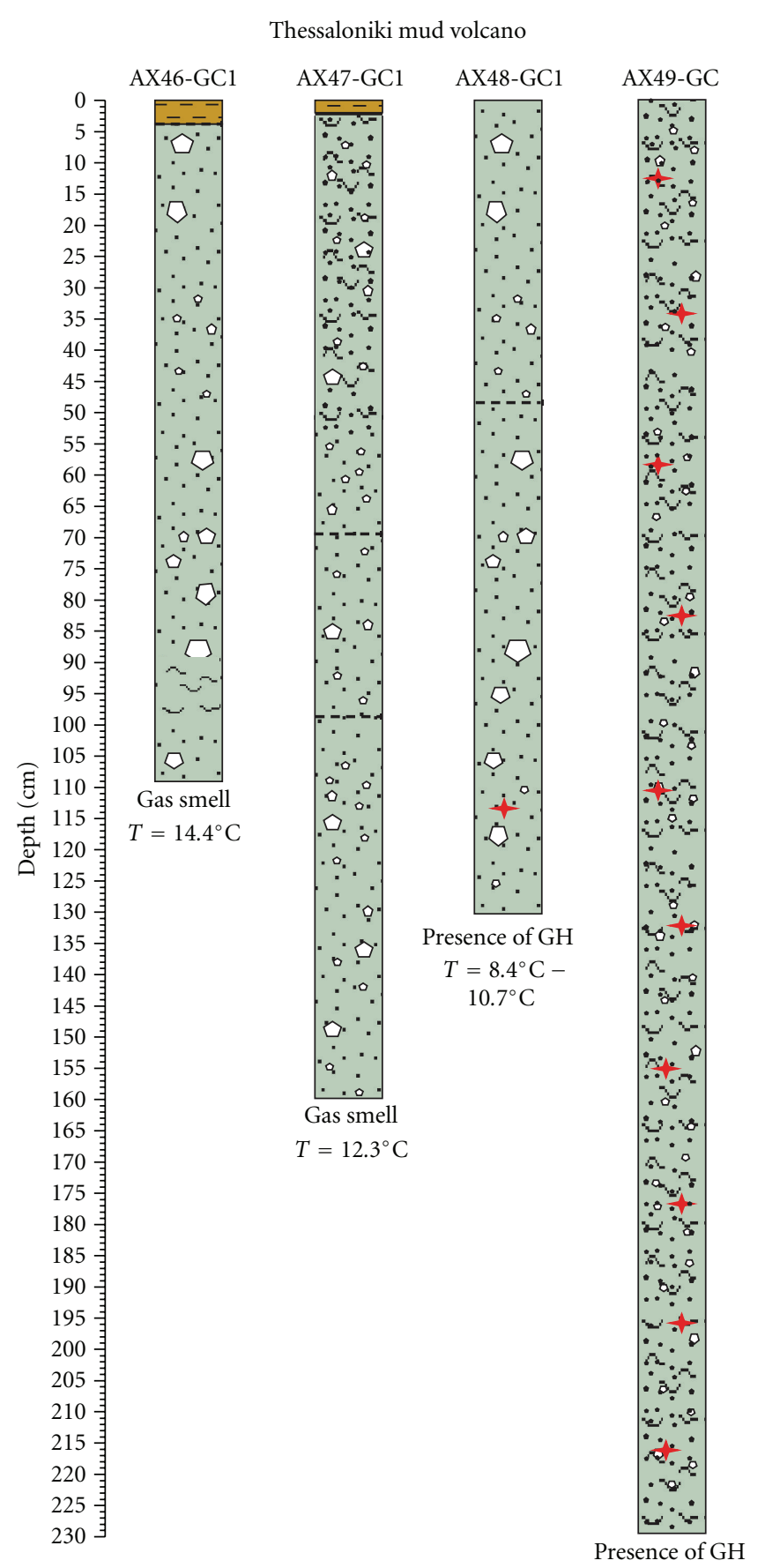

seafloor as mud breccia. In this case they represent basement units associated with the Lycian Nappes and Bey Dağları to the north in Turkey $[6,7,23-25]$. Porous gas-release structures are common in the sediment we observed because much of the disseminated gas hydrates, associated with this type of sediment, dissociated during the sampling operation or minutes later onboard, where the ambient P-T conditions indicate that gas hydrates are unstable $[26,27]$. Similar sediment has been described in other mud volcanoes (Amsterdam, Kula, and Kazan) in the area [17, 24, 28].

Core AX46-GC1 (Figure 3) was retrieved from the southern peak ( $1263 \mathrm{~m}$ water depth; core length of $119 \mathrm{~cm}$ ). The top $5 \mathrm{~cm}$ is composed of a yellowish gray oxidized mud layer with faint laminae supporting dispersed small clasts $<1.5 \mathrm{~cm}$ in diameter. There is a gradual change in color downwards toward the next 5 to $19 \mathrm{~cm}$ section which is a greenish-gray reduced mud containing a few clasts up to $3 \mathrm{~cm}$ in diameter. The following 19-119 section is similar in color with the overlying section but with larger clasts, up to $5 \mathrm{~cm}$ in diameter and increasing in the lower $10 \mathrm{~cm}$. Evidence of dewatering features associated with a strong gas smell were also noted. The sediment temperature upon opening of the core was $14.4^{\circ} \mathrm{C}$, roughly (actually, just above) seafloor temperature. No gas hydrates were detected.

On the same southern peak at a distance of about $80 \mathrm{~m}$ to the north and at a depth of $1265 \mathrm{~m}$ core AX47-GC1 was collected with a length of $167 \mathrm{~cm}$ (Figure 3). The sediment temperature upon opening was $12.3^{\circ} \mathrm{C}$. At the top of the core there was a $3 \mathrm{~cm}$ thick yellowish gray oxidized layer followed by a $3-78 \mathrm{~cm}$ section of dark reduced greenishgray mud with occasional clasts. The sediment is more soupy in the top $41 \mathrm{~cm}$ of the section becoming stiffer below, with faint laminae at 64 to $65 \mathrm{~cm}$. The next 78 to $167 \mathrm{~cm} \mathrm{sec}-$ tion contains larger rock clasts, up to $2.5 \mathrm{~cm}$ across, and two dark gray-colored laminated layers at $79-85 \mathrm{~cm}$ and at $96-$ $99 \mathrm{~cm}$. The sediment becomes stiff at the bottom of the layer. No GH were found.

On the northern peak a $130 \mathrm{~cm}$ long core (AX48-GC1, Figure 3) was retrieved from a water depth of $1264 \mathrm{~cm}$. The sediment temperature when measured on deck varied between 8.4 and $10.7^{\circ} \mathrm{C}$. No oxidized layer was observed at the top of the core, indicating relatively recent mud volcanic activity in this area (because the upper part of the mud breccias had not had time to oxidize nor to be overlain by semipelagic sediment typical of the local seafloor). The sediment consists of greenish-gray mud with large rock clasts dispersed throughout the whole length of the core. The GH were observed mainly between 110 and $120 \mathrm{~cm}$ where their dissociation produced many degassing features resulting in the soft and sometimes soupy texture of the sediment (Figure 4). Most of the large rock clasts occur in the lower section of the core, where the sediment becomes stiffer below a core depth of $55 \mathrm{~cm}$.

Core AX49-GC1 (Figure 3) was the longest core taken $(228 \mathrm{~cm})$ and also comes from the northern peak at the same location and water depth as core AX48-GC1. It consists of gray mud with foamy mousse-like texture and consistency,

Figure 3: Description of the gravity cores. 


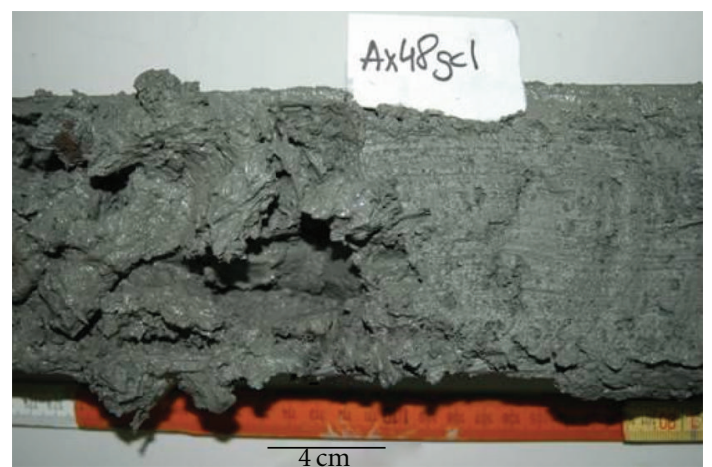

Figure 4: Section $99-124 \mathrm{~cm}$ of core AX48-GC1. Note the soft character of section $110-120 \mathrm{~cm}$ which contained gas hydrates.

with many degassing features produced from the dissociation of GH dispersed throughout the whole length of the core.

3.3. Geochemical Results. A geochemical analysis was made of both the mud flow (trace element) and the rock clasts (main element) of the gravity cores.

The results of the trace element analysis in the mud flow of two gravity cores (Table 2(a)) indicate that organic carbon $\left(\mathrm{C}_{\text {org }}\right), \mathrm{Na}_{2} \mathrm{O}, \mathrm{Mg}, \mathrm{Rd}, \mathrm{Sr}$, and $\mathrm{Cu}$ do not vary down core. The total carbon $\left(\mathrm{C}_{\mathrm{tot}}\right)$ is higher at the top of the cores than in the lower sections whereas the values of $\mathrm{S}$ and $\mathrm{Zn}$ are usually lower at the top of the cores than below.

Calcite is the dominant mineral in the rock clasts from gravity core AX 48-GC1 (Table 2(b)). This combined with the presence of the other main elements shown in Table 2(b), and the low dolomite content, support earlier interpretations that bedrock here is related to the Miocene flysch deposits present on land to the north ([6] see Section 3.4).

These results also indicate that the composition of the Thessaloniki MV sediments are comparable to those reported in other Mediterranean mud volcanoes like Athina [20] and even those from the Gulf of Cadiz [29].

The methane concentration was measured in both gravity cores. No gas hydrates were observed in core AX47GC1 but the sediment was wet and in some places "soupy." On the other hand, gas hydrates were observed throughout core AX49-GC1 when it was opened on deck (Figures 3 and 4). Methane concentrations in core AX47-GC1 were about $2800 \mu \mathrm{moL} / \mathrm{kg}$ wet sediment, with a maximum of $4000 \mu \mathrm{moL} / \mathrm{kg}$ wet sediment at a core depth below sea floor of $100 \mathrm{~cm}$. In core AX49-GC1, the methane concentration was $3000 \mu \mathrm{moL} / \mathrm{kg}$ wet sediment, decreasing to $2000 \mu \mathrm{moL} / \mathrm{kg}$ wet sediment below this maximum at $100 \mathrm{~cm}$ down core (Figure 5). Thus the methane concentrations at both western highs on the summit of the mud volcano were high despite the apparent differences in gas hydrate content seen in the sediment. However, due to the degassing of these conventional cores during recovery, and the consequent loss of up to $90 \%$ of the methane [19], we could not determine significant differences in methane concentrations because the concentrations are far below methane saturation in the presence of gas hydrates $(\sim 100 \mathrm{mmoL} / \mathrm{kg}$ pore water [19]).
It is possible that observations of gas hydrates in one core, but not in another with similar concentrations of methane, can be explained by differences in the size of the gas hydrate deposits between the two cores, with the smaller GH crystals disappearing more quickly.

The in situ methane concentration in the autoclave core at northern site AX49 (core AX49-AP1) was calculated to be about $180 \mathrm{mmoL} / \mathrm{kg}$ pore water at depths where there is no sulfate present. To calculate gas hydrate volumes from methane concentrations in relation to the core volume, the amount of collected gas $\left(\sum \mathrm{CH}_{4}=3.1 \mathrm{~L}\right)$ is related to the core volume between the bottom of the core and the sulfate depletion depth, assuming an even distribution throughout this depth range with dissolved and hydrate-bound $\mathrm{CH}_{4}$ to be present. The saturation concentration $\left(\mathrm{c}_{\mathrm{eq}}\right)$ of $\mathrm{CH}_{4}$ is subtracted before calculating gas hydrate volumes. For details see [30]. In core AX49-AP1 gas hydrates occupy about $0.7 \%$ of the core volume. The gas collected from the pressure core is nearly devoid of propane and butane thus allowing structure I gas hydrates to be formed [19]. No pressure corer was taken on the southern peak of this western high.

3.4. Study of the Mud Breccia Rock Clasts. The presence of a yellowish-brown oxidized layer in the upper few centimetres of the two gravity cores, where there were no gas hydrates observed, probably indicates that at these two sites mud volcano activity was low to absent during the last few hundred years. Freshly erupted mud breccia is characterised by grey reduced sediment and the lack of an oxidised hemipelagic sediment cover. An estimate of the age of eruptions can sometimes be made using the thickness of the overlying sediment and a good estimate of the rate of sedimentation, in this area about $2-5 \mathrm{~cm} / \mathrm{ka}$ [24]. The composition of the mud in all cores was mainly silty clays with a sand fraction between 5 to $7 \%$ and a mean grain size between 6.2 and 7.8 phi; it is consisted of terrigenous material with minor amounts of biogenic components, mainly planktonic foraminifera.

As noted previously, rock clasts that erupted through a mud volcano are comprised of a chaotic mixture of material from the overpressurized source formation and the rock units through which the eruption occurred. This material can provide significant geological information about the deeper geological units underlying the mud volcano, as well as the stratigraphy. A litho-micropalaeontological study of 39 samples of mud breccia clasts from Thessaloniki MV was undertaken.

These rock clasts of various size $(2-5 \mathrm{~cm}$ in length) and supported in a homogeneous mud breccia matrix were sampled from the gravity cores collected during the second cruise of the ANAXIMANDER project. They were subsequently washed and classified by their general characteristics (composition, color, grain size, reaction with $\mathrm{HCl}$, and roundness). Several clasts were selected then for further thin section analysis using a NIKON polarizing petrographic microscope. The most informative samples were also washed and sieved through a $150 \mu \mathrm{m}$ sieve. This fraction is also used for analyzing the planktonic foraminifera assemblages. Typical examples of thin sections are shown in Figure 6. 
TABle 2: (a) Trace element analysis of the mud flow in cores AX48GC1 and AX49GC1. (b) Main element analysis (\%) of the rock clasts from core AX48-GC1.

(a)

\begin{tabular}{lcccccccccc}
\hline Core & Sample depth $(\mathrm{cm})$ & $\mathrm{C}_{\text {tot* } \%}$ & $\mathrm{C}_{\text {org* } \%}$ & $\mathrm{~S} \%$ & $\mathrm{Na}_{2} \mathrm{O} \%$ & $\mathrm{Mg} \%$ & $\mathrm{Sr} \%$ & $\mathrm{Rb} \%$ & $\mathrm{Zn} \mathrm{ppm}$ & $\mathrm{Cu} \mathrm{ppm}$ \\
\hline AX48GC1 & $9 \mathrm{~cm}$ & 2,57 & 0,37 & 0,27 & 1,48 & 0,142 & 0,022 & 0,08 & 87 & 56 \\
$\prime \prime$ & $30 \mathrm{~cm}$ & 2,05 & 0,35 & 0,44 & 1,75 & 0,146 & 0,019 & 0,10 & 94 & 78 \\
$\prime \prime$ & $65 \mathrm{~cm}$ & 2,20 & 0,32 & 0,48 & 1,62 & 0,134 & 0,027 & 0,08 & 100 & 74 \\
$\prime \prime$ & $110 \mathrm{~cm}$ & 1,70 & 0,32 & 0,40 & 1,75 & 0,137 & 0,023 & 0,08 & 104 & 78 \\
AX49GC1 & $12 \mathrm{~cm}$ & 2,85 & 0,44 & 0,58 & 1,75 & 0,151 & 0,024 & 0,09 & 89 & 73 \\
$\prime \prime$ & $50 \mathrm{~cm}$ & 2,25 & 0,48 & 0,62 & 1,75 & 0,150 & 0,023 & 0,09 & 102 & 72 \\
$\prime \prime$ & $70 \mathrm{~cm}$ & 1,45 & 0,39 & 0,48 & 1,75 & 0,158 & 0,016 & 0,08 & 86 & 69 \\
$\prime \prime$ & $105 \mathrm{~cm}$ & 1,75 & 0,43 & 0,58 & 1,62 & 0,146 & 0,023 & 0,08 & 94 & 76 \\
\hline
\end{tabular}

(b)

\begin{tabular}{lc}
\hline Mineral & $\%$ \\
\hline Calcite & 57 \\
Quartz & 12 \\
Montmorillonite & 5 \\
Kaolinite & 8 \\
Glaucophane & 4 \\
Albite & 6 \\
$\mathrm{SiO}_{2}$ & 5 \\
Dolomite & 3 \\
\hline
\end{tabular}

${ }^{*} \mathrm{C}_{\text {tot }}$ is total carbon, $\mathrm{C}_{\mathrm{org}}$ is organic carbon.

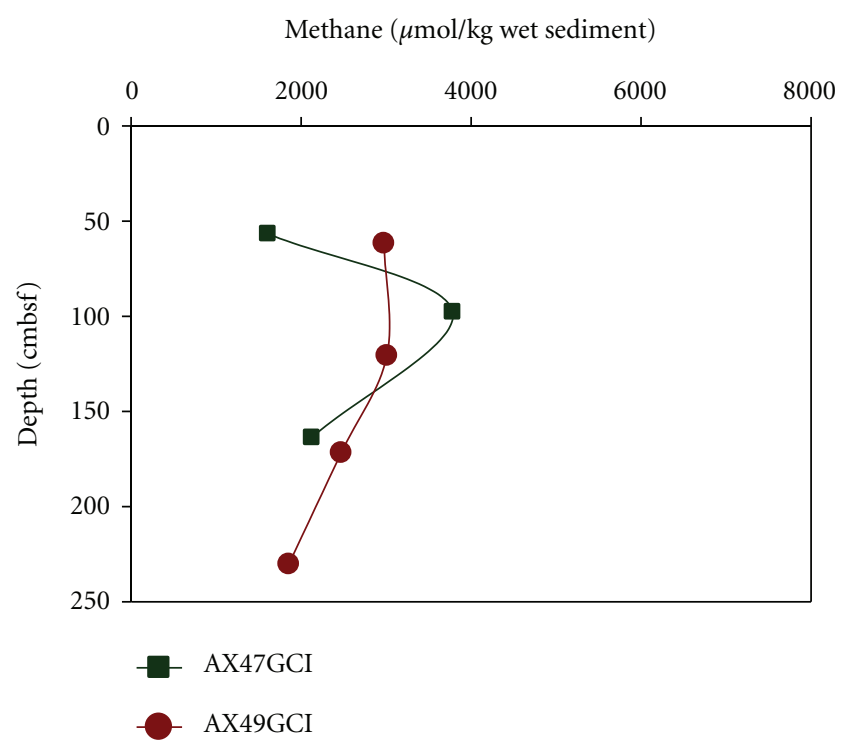

Figure 5: Methane concentrations of one of the southern (AX47GG1) and northern (AX49-GG1) gravity core stations at Thessaloniki MV.

Rock clasts from the Thessaloniki MV cores (AX46GC1, AX47GC1, AX48GC1, AX49GC1, and AX49AP1) belong to two rock groups: fossiliferous micrites and detrital biomicrites. Both these two groups were recognized also in the other ANAXIMANDER mud volcanoes during this project $[24,25]$. The fossiliferous micrites exhibit mainly an angular-subangular form, are small in size, have lightgray colour, are consolidated, and contain (10-60\%) wellpreserved pelagic foraminifera in a micritic calcite matrix. The foram chambers are usually filled by sparitic calcite or pyrite. The planktonic species present are Orbulina suturalis, Globigerinoides trilobus, Globigerinoides sp., and Globoquadrina dehiscens, which indicate a Lower to Middle Miocene age and an open marine environment $[17,24,31]$. The detrital biomicrites are angular-subangular in form, graybrown in colour, contain tests and fragments of planktonic foraminifera, with fine grained aggregates of calcite and silty sized angular quartz grains in a micritic arenite matrix. Among the main fossils recognized are the species Orbulina universa, Orbulina suturalis, Globigerinoides trilobus, Globoquadrina nepethens, and Globigerinoides obliquus. which indicate an Upper Miocene age [31], and an open marine depositional environment.

Comparable microfaunal associations of Miocene deposits were also identified in the clasts sampled by gravity coring in the upper parts of mud flows in Amsterdam, Athina, Kazan, and Kula MVs. These data support the conclusion that part of the basement of the Anaximander Mountains in this area contains Miocene deposits that are comparable in age and facies with the geological units of the neighbouring land area of SW Turkey. Considering that these units are probably in situ, it can be concluded that the onshore Miocene flysch deposits of the Antalya Complex $[24,31]$ extend southward into the Anaximenes and Anaximander Mountains, thus supporting similar conclusions by Woodside et al. and other authors $[6,7,12,32,33]$. 


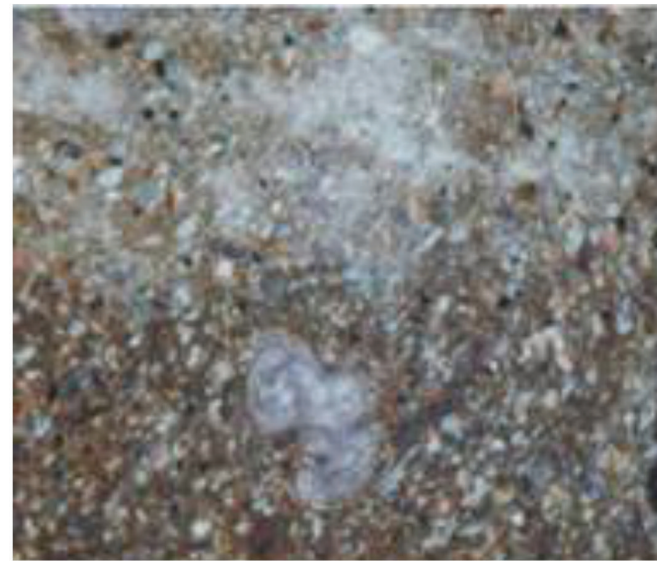

(a)

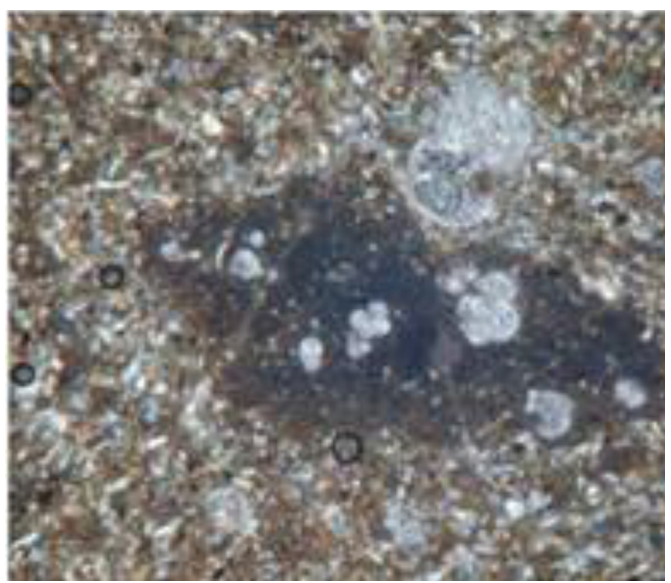

(c)

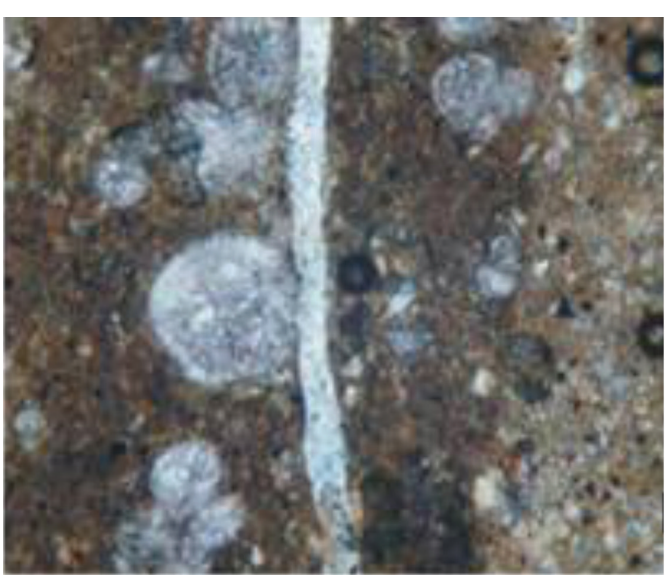

(b)

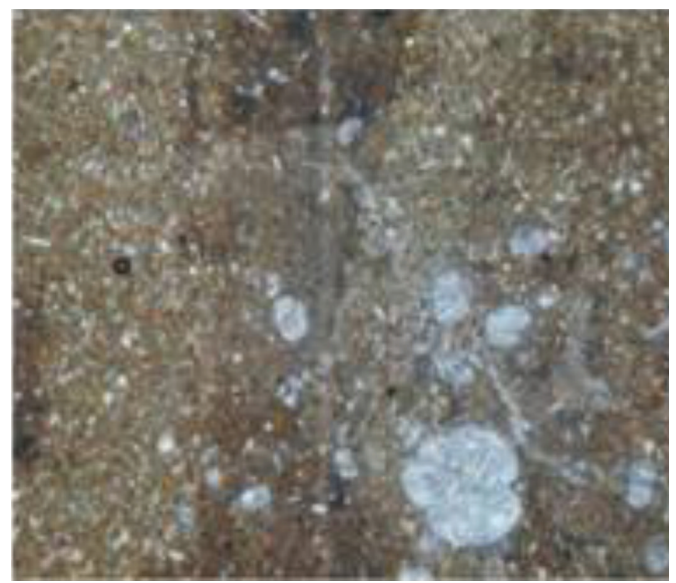

(d)

Figure 6: (a-d) Polarized microscope pictures of thin sections of mud breccia rock clasts; bioclastic carbonate pack/wackestones (grading into mudstones/claystones) with Globigerinidae planktonic foraminifera.

\section{Gas Hydrate Stability Field}

As noted above, the sediment cores with gas hydrates were all from relatively recently erupted mud breccia, as indicated by the lack of hemipelagic cover or surface oxidation of the mud flow. Thessaloniki MV is the shallowest mud volcano bearing gas hydrates in the Mediterranean $(1265 \mathrm{~m})$. At this depth the gas hydrates are just within, and near the edge of the gas hydrate stability zone (Figures 7(a) and 7(b)) as determined by the pressure (12.9 Mpa at $1265 \mathrm{~m}$ depth) and seafloor temperature $\left(\sim 14^{\circ} \mathrm{C}\right)$. The field data collected at Thessaloniki MV indicated that the GH occur at $1265 \mathrm{~m}$ sea floor depth and in subbottom sedimentary layers at least to $220 \mathrm{~cm}$ below seafloor. The sea bottom water temperature is $13.75^{\circ} \mathrm{C}$ and the geothermal gradient is expected to be $30-35^{\circ} \mathrm{C} / \mathrm{Km}$ or more, based on heat flow measurements made in the Olimpi mud diapir field [34]. During the MIMES cruise in 2004, one heat flow measurement made by Feseker and Foucher on Amsterdam Mud Volcano showed a significant warming of the sediments by over $3^{\circ} \mathrm{C}$ in the upper $10 \mathrm{~m}$ of mud $[35,36]$. In other mud volcano areas the heat flow implies much higher geothermal gradients which, for example, were as high as $2.78^{\circ} \mathrm{C} / \mathrm{m}$ in the active centre of Isis mud volcano [35].

A gas hydrate stability diagram, based on the parameters just described, indicates (Figures 7 (a) and 7(b), $[27,36]$ ) that the gas hydrates at Thessaloniki MV are just at the limit for the occurrence of stable methane hydrate, and do not extend more than a few meters above the known Thessaloniki MV depth. This means that with only small changes in the environmental parameters the gas hydrates could disassociate releasing water and methane. Such changes could result from a decrease in seafloor pressure (e.g., by tectonic uplift or sea level decrease) or by slight increase in the bottom water temperature (e.g., from an event like the recent increase in bottom water temperature in the Ionian Sea [37]). These small changes in temperature and sea level are both possible and sufficient to destabilize the gas hydrates at Thessaloniki MV.

Although the amount of methane produced from the autoclave core from Thessaloniki MV is minor in quantity, and the volume of gas hydrates is unlikely to be large at this site (based on the maximum depth at which gas hydrates in this area can be stable, as indicated in Figures 7(a) and $7(\mathrm{~b})$ ), we do not know the potential areal extent of the GH 


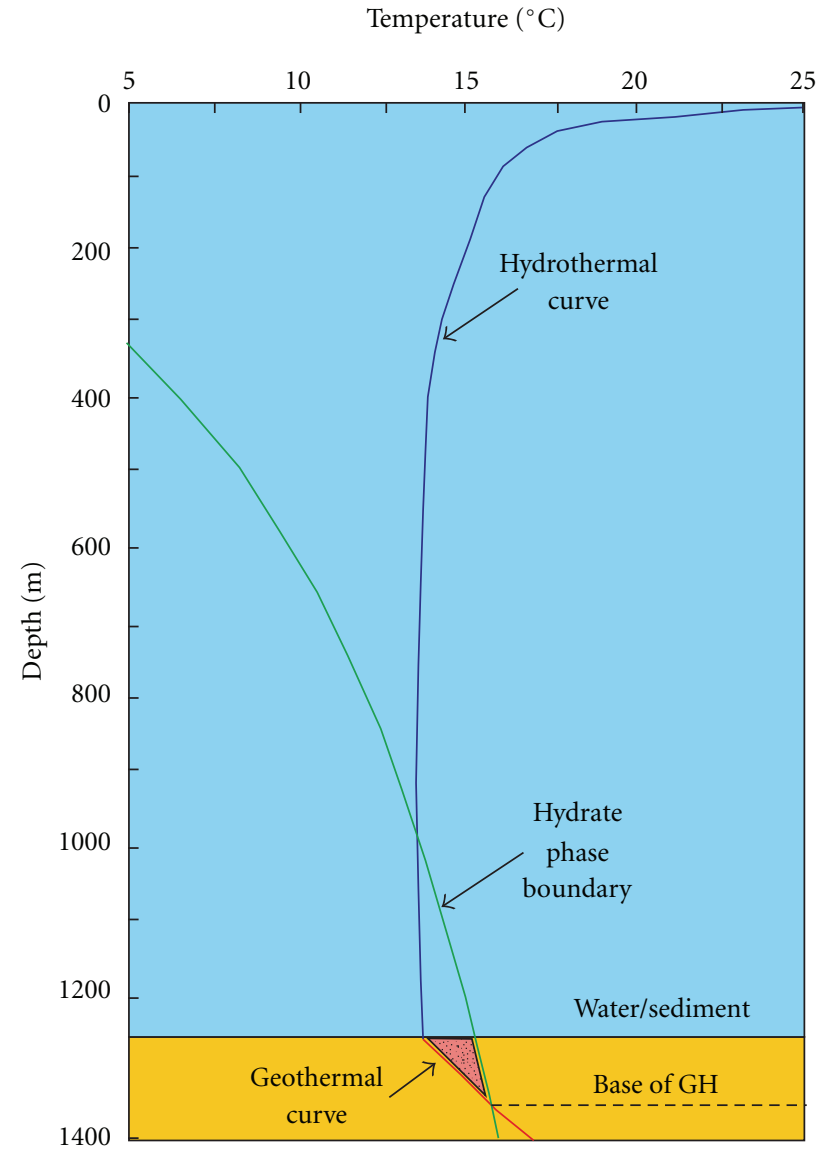

(a)

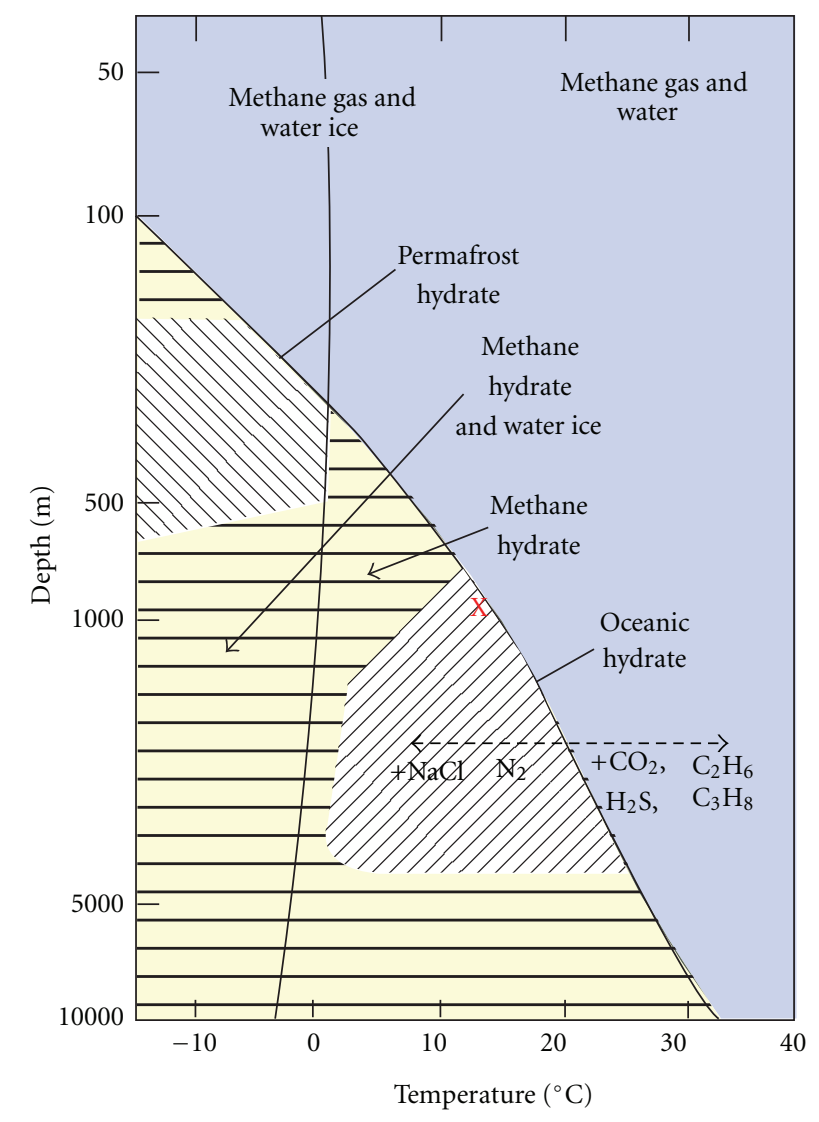

(b)

Figure 7: (a) Gas hydrate stability diagram for the Thessaloniki MV greater area (based on [36]), (b) gas hydrate stability diagram [27] depicting with an $\mathrm{X}$ the location of Thessaloniki gas hydrate field.

at these water depths in the Eastern Mediterranean. Since these GH are at the upper boundary of the GH stability diagram their distribution and presence should be studied more thoroughly.

\section{Conclusion}

A new gas hydrate bearing mud volcano named Thessaloniki was discovered in the Anaximander Mountains on the basis of its seafloor expression and an analysis of cores containing gas hydrates in a matrix of mud breccia typical of mud volcanoes. It is the shallowest mud volcano there, lying at depths between 1315 and $1260 \mathrm{~m}$, with an areal extend of about $1.67 \mathrm{~km}^{2}$ and comprising three peaks on its summit. GH were collected from three cores (two conventional gravity cores and one autoclave core). The GH crystals have the form of flakes or rice. The degassing of the $228 \mathrm{~cm}$ long autoclave core provided 3.1 liters of gas (mostly methane). Rock clasts from the mud breccias indicate a lower middle Miocene age for the source rock formation. The sea bottom temperature $\left(13.7^{\circ} \mathrm{C}\right)$ and the pressure $(12.9 \mathrm{MPa})$ at Thessaloniki MV indicate that the $\mathrm{GH}$ there are at the upper limit of the stability zone, and prone to dissociation with the slightest temperature increase or pressure decrease. Therefore it could be a particularly suitable site for studying not only the mud volcano activity, but also the stability of natural gas hydrates and their potential environmental impact should they dissociate.

\section{Acknowledgments}

The field and office work was supported by the EC-funded projects ANAXIMANDER (EVK-CT-2002-20068) and HERMES (GOCE-CT-2005-511234-1) which the authors greatly appreciate. The authors thank the officers and the crew of the R/V Aegaeo for their important and effective contribution during the field work. They also thank the anonymous reviewers for the useful comments and suggestions.

\section{References}

[1] A. H. F. Robertson and A. Kopf, "Tectonic setting and processes of mud volcanism on the Mediterranean Ridge 
accretionary complex: evidence from Leg 160," in Proceedings of the Ocean Drilling Program, Scientific Results, A. H. F. Robertson, K.-C. Emeis, C. Richter, and A. Camerlenghi, Eds., vol. 160, pp. 665-680, 1998.

[2] C. Perissoratis, G. Papadopoulos, and E. Zimianitis, "Occurrence of mud diapirism in the marine sector between Kos and Kalimnos islands, SE Aegean : preliminary Results," Bulletin of the Geological Society of Greece, vol. 32, no. 2, pp. 217-222, 1998.

[3] C. W. Holland, G. Etiope, A. V. Milkov, E. Michelozzi, and P. Favali, "Mud volcanoes discovered offshore Sicily," Marine Geology, vol. 199, no. 1-2, pp. 1-6, 2003.

[4] C. Huguen, J. Mascle, E. Chaumillon, A. Kopf, J. Woodside, and T. Zitter, "Structural setting and tectonic control of mud volcanoes from the Central Mediterranean Ridge (Eastern Mediterranean)," Marine Geology, vol. 209, no. 1-4, pp. 245263, 2004.

[5] A. V. Milkov, "Worldwide distribution of submarine mud volcanoes and associated gas hydrates," Marine Geology, vol. 167, no. 1-2, pp. 29-42, 2000.

[6] J. Woodside, "Neotectonic Deformation of the Anaximander Mountains observed from EM12D multibeam data," in Sedimentary Basins of the Mediterranean and Black Seas. TTR, 4th Post-Cruise Meeting UNESCO Report, pp. 11-12, 1996.

[7] J. M. Woodside, M. K. Ivanov, and A. F. Limonov, "Shallow gas and gas hydrates in the Anaximander Mountains region Eastern Mediterranean Sea," in Gas Hydrates: Relevance to World Margin Stability and Climate Change, J. P. Henriet and J. Mienert, Eds., Sp. Publ. 137, pp. 177-193, Geological Society, London, UK, 1998.

[8] L. Loncke and J. Mascle, "Mud volcanoes, gas chimneys, pockmarks and mounds in the Nile deep-sea fan (eastern Mediterranean); geophysical evidences," Marine and Petroleum Geology, vol. 21, pp. 669-689, 2004.

[9] J. Mascle, T. Zitter, G. Bellaiche, L. Droz, V. Gaullier, and L. Loncke, "The Nile deep sea fan: preliminary results from a swath bathymetry survey," Marine and Petroleum Geology, vol. 18, pp. 471-477, 2001.

[10] J. H. ten Veen, J. M. Woodside, T. A. C. Zitter, J. F. Dumont, J. Mascle, and A. Volkonskaia, "Neotectonic evolution of the Anaximander Mountains at the junction of the Hellenic and Cyprus arcs," Tectonophysics, vol. 391, no. 1-4, pp. 35-65, 2004.

[11] J. M. Woodside and S. Dupre, "Cruise Report MIMES: an Expedition on Pelagia 13 June 2004-July 2004 (a contribution to the MEDIFLUX project of EUROMARGINS)," NWOALW project 855.01.031, 2004.

[12] T. A. C. Zitter, C. Huguen, and J. M. Woodside, "Geology of mud volcanoes in the eastern Mediterranean from combined sidescan sonar and submersible surveys," Deep-Sea Research Part I, vol. 52, no. 3, pp. 457-475, 2005.

[13] M. B. Cita, W. F. B. Ryan, and 1. Paggi, "Prometheus mud breccia: an example of shale diapirism in the western Mediterranean ridge," Annales Géologiques des Pays Helleniques, vol. 3, pp. 543-570, 1981.

[14] T. A. C. Zitter, J. M. Woodside, and J. Mascle, "The Anaximander Mountains: a clue to the tectonics of southwest Anatolia," Geological Journal, vol. 38, no. 3-4, pp. 375-394, 2003.

[15] A. E. Aksu, J. Hall, and C. Yaltirak, "Miocene-recent evolution of Anaximander Mountains and Finike Basin at the junction of Hellenic and Cyprus Arcs, eastern Mediterranean," Marine Geology, vol. 258, no. 1-4, pp. 24-47, 2009.
[16] S. McClusky, S. Balassanian, A. Barka et al., "Global positioning system constraints on plate kinematics and dynamics in the eastern Mediterranean and caucasus," Journal of Geophysical Research B, vol. 105, no. 3, pp. 5695-5719, 2000.

[17] V. Lykousis, S. Alexandri, J. Woodside et al., "Mud volcanoes and gas hydrates in the Anaximander mountains (Eastern Mediterranean Sea)," Marine and Petroleum Geology, vol. 26, no. 6, pp. 854-872, 2009.

[18] T. Pape, S. Kasten, M. Zabel et al., "Gas hydrates in shallow deposits of the Amsterdam mud volcano, Anaximander Mountains, northeastern Mediterranean Sea," Geo-Marine Letters, vol. 30, no. 3-4, pp. 187-206, 2010.

[19] K. Heeschen, A. Dahlmann, H.-J. Hohnberg et al., "Pressurized near-surface sediment cores of Anaximander mud volcanoes," in Eastern Mediterranean, EGU General Assembly, vol. 8 of Geophysical Research Abstracts, Vienna, Austria, April 2006, 07005. SRef-ID: 1607-7962/gra/EGU06-A-07005.

[20] V. Lykousis, S. Alexandri, J. Woodside et al., "New evidence of extensive active mud volcanism in the Anaximander mountains (Eastern Mediterranean): the "ATHINA" mud volcano," Environmental Geology, vol. 46, no. 8, pp. 1030-1037, 2004.

[21] C. Perissoratis, Chr. Ioakim, V. Lykousis et al., "Characteristics of the Thessaloniki Mud Volcano, a recently discovered gas hydrate bearing area in the Anaximander Mountains," in Eastern Mediterranean, EGU General Assembly, vol. 8 of Geophysical Research Abstracts, Vienna, Austria, April 2006, 03874, SRef-ID: 1607-7962/gra/EGU06-A-03874.

[22] H. Amann, J. Baraza, C. Marx et al., "HYACE, an Autoclave coring equipment for systematic offshore sampling, measurement and ground truthing," in Eurocean, pp. 670-673, 2000.

[23] C. Huguen, J. Benkhelil, P. Giresse et al., "Échantillons rocheux provenant de "volcans de boue" de Méditerranée orientale," Oceanologica Acta, vol. 24, no. 4, pp. 349-360, 2001.

[24] Chr. Ioakim, St. Tsaila-Monopolis, C. Perissoratis, and V. Lykousis, "The examination of the gas hydrates hosting environment at the Anaximander Mud Volcanoes, Eastern Mediterranean: stratigraphy and Sedimentary successions at the mud beacia clasts," in CIESM Workshop Monograph, vol. 29, pp. 87-96, Bologna, Italy, 2005.

[25] Chr. Ioakim, St. Tsaila-Monopolis, C. Perissoratis, V. Lykousis, S. Alexandri, and J. Woodside, "Deciphering the deep geology of the Anaximander Mountains area (Eastern Mediterranean)," in Proceedings of the 3rd Geological Congres, 2008, abstract.

[26] K. A. Kvenvolden, "Gas hydrates-geological perspective and global change," Reviews of Geophysics, vol. 31, no. 2, pp. 173187, 1993.

[27] R. E. Pellenberg and D. Max, "Introduction, physical properties, and natural occurrences of hydrate," in Natural Gas Hydrate: in Oceanic and Permafrost Environments, D. Max, Ed., vol. 5, pp. 1-8, Kluwer Academic Publishers, Dordrecht, The Netherlands, 2000.

[28] D. Casas, G. Ercilla, V. Lykousis, Chr. Ioakim, and C. Perissoratis, "Physical properties and their relationship to sedimentary processes and texture in sediments from mud volcanoes in the Anaximander Mountains (Eastern Mediterranean)," Scientia Marina, vol. 70, no. 4, pp. 643-659, 2006.

[29] V. H. Magalhaes, J. Bobos, L. Gaspar, L. M. Pinheiro, J. H. Monteiro, and M. K. Ivanov, "Mineralogy and geochemistry of carbonate chimneys from the Gulf of Cadiz: preliminary results," IOC Workshop Report no. 183, 2002. 
[30] K. U. Heeschen, H. J. Hohnberg, M. Haeckel, F. Abegg, M. Drews, and G. Bohrmann, "In situ hydrocarbon concentrations from pressurized cores in surface sediments, Northern Gulf of Mexico," Marine Chemistry, vol. 107, no. 4, pp. 498$515,2007$.

[31] H. Bolli and J. Saunders, "Oligocene to Holocene low latitude planctonic foraminifera," in Planctonic Stratigraphy, H. Bolli, J. Saunders, and G. Perch-Nielsen, Eds., pp. 155-263, Cambridge University Press, Cambridge, UK, 1985.

[32] M. Gutnic, O. Monod, A. Poisson, and J. F. Dumont, "Geologie des Taurides Occidentales (Turquie)," Mémoires de la Société Géologique de France, vol. 137, pp. 1-112, 1979.

[33] T. A. C. Zitter, Mud volcanism and fluid emissions in Eastern Mediterranean neotectonic zones, Ph.D. thesis, Vrije University, 2004.

[34] A. Camerlenghi, M. B. Cita, B. Della Vedova, N. Fusi, L. Mirabile, and G. Pellis, "Geophysical evidence of mud diapirism on the Mediterranean Ridge accretionary complex," Marine Geophysical Researches, vol. 17, no. 2, pp. 115-141, 1995.

[35] T. Feseker, A. Dählmann, J. P. Foucher, and F. Harmegnies, "In-situ sediment temperature measurements and geochemical porewater data suggest highly dynamic fluid flow at Isis mud volcano, eastern Mediterranean Sea," Marine Geology, vol. 261, no. 1-4, pp. 128-137, 2009.

[36] E. D. Sloan, "Natural gas hydrate phase equilibria and kinetics: understanding the state-of-the-art," Revue de l'Institut Francais du Petrole, vol. 45, no. 2, pp. 245-266, 1990.

[37] B. Klein, W. Roether, B. B. Manca et al., "The large deep water transient in the Eastern Mediterranean," Deep-Sea Research Part I, vol. 46, no. 3, pp. 371-414, 1999. 

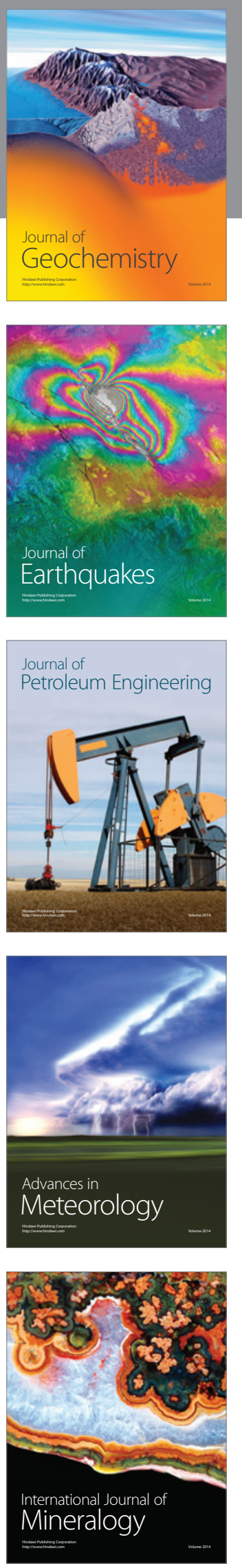
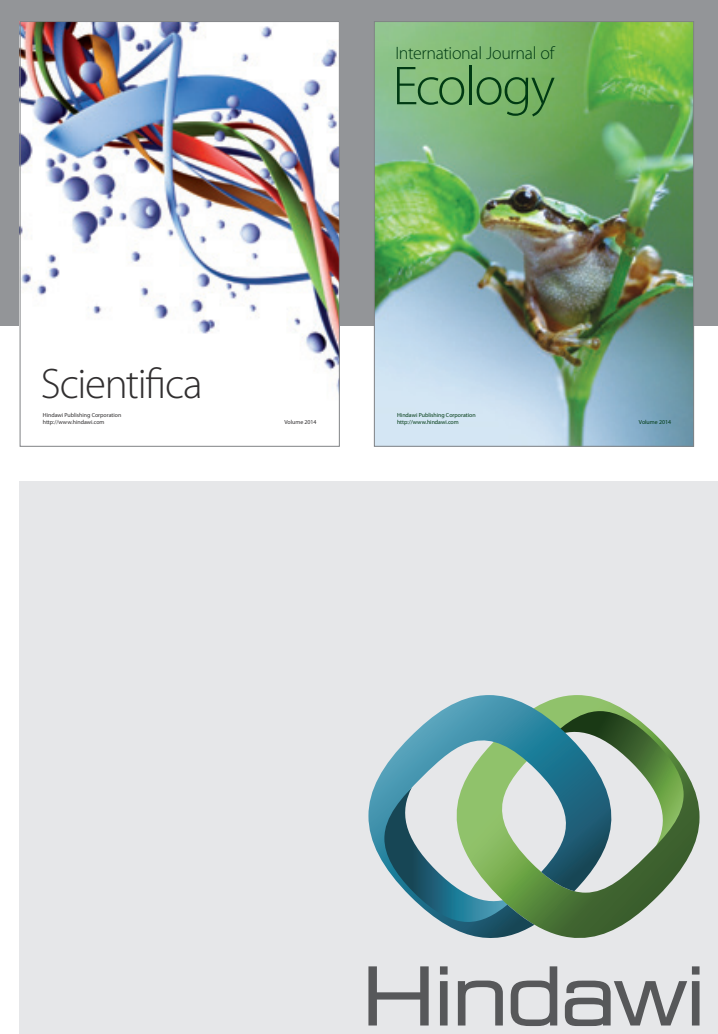

Submit your manuscripts at http://www.hindawi.com
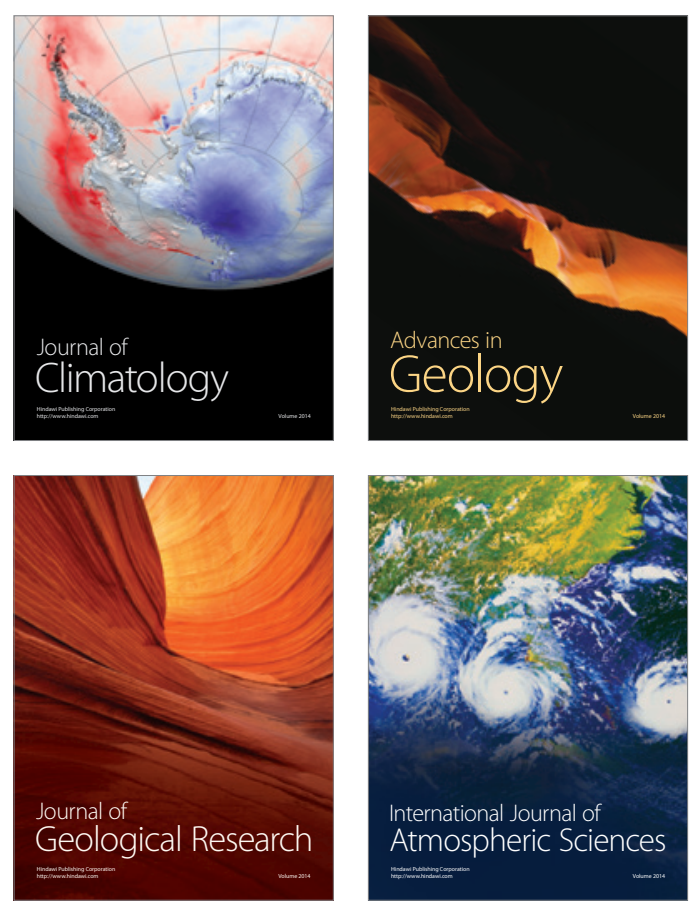
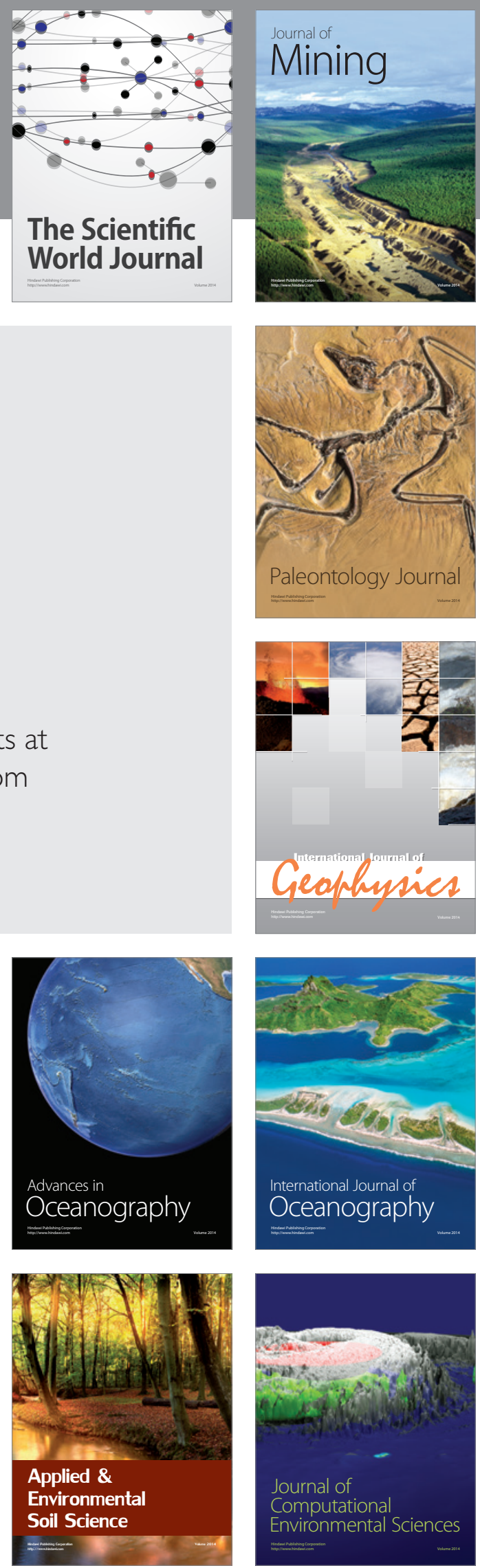